\title{
Worsening Renal Function Defined as an Absolute Increase in Serum Creatinine Is a Biased Metric for the Study of Cardio-Renal Interactions
}

\author{
Jeffrey M. Testani Brian D. McCauley Jennifer Chen Michael Shumski \\ Richard P. Shannon \\ Department of Medicine, Cardiovascular Division, University of Pennsylvania, Philadelphia, Pa., USA
}

\section{Key Words}

Cardio-renal syndrome $\cdot$ Decompensated heart failure $\cdot$

Worsening renal function

\begin{abstract}
Objectives: Worsening renal function (WRF) during the treatment of decompensated heart failure, frequently defined as an absolute increase in serum creatinine $\geq 0.3 \mathrm{mg} /$ $\mathrm{dl}$, has been reported as a strong adverse prognostic factor in several studies. We hypothesized that this definition of WRF is biased by baseline renal function secondary to the exponential relationship between creatinine and renal function. Methods: We reviewed consecutive admissions with a discharge diagnosis of heart failure. An increase in creatinine $\geq 0.3 \mathrm{mg} / \mathrm{dl}\left(\mathrm{WRF}_{\mathrm{CREAT}}\right)$ was compared to a decrease in GFR $\geq 20 \%\left(\mathrm{WRF}_{\mathrm{GFR}}\right)$. Results: Overall, 993 admissions met eligibility. $\mathrm{WRF}_{\text {CREAT }}$ occurred in $31.5 \%$ and $\mathrm{WRF}_{\text {GFR }}$ in $32.7 \%$. $W_{\text {RFF }}$ CRET and $W_{\text {RFF }}$ Gad opposing relationships with baseline renal function ( $O R=1.9$ vs. $O R=0.51$, respectively, $p<0.001)$. Both definitions had similar unadjusted associations with death at 30 days $\left[\mathrm{WRF}_{\mathrm{GFR}} \mathrm{OR}=2.3(95 \% \mathrm{Cl} 1.1-4.8)\right.$, $\mathrm{p}=0.026 ; \mathrm{WRF}_{\text {CREAT }} \mathrm{OR}=2.1$ (95\% Cl 1.0-4.4), $\mathrm{p}=0.047$ ]. Controlling for baseline renal insufficiency, $\mathrm{WRF}_{\mathrm{GFR}}$ added incrementally in the prediction of mortality $(p=0.009)$; however, WRF $_{\text {CREAT }}$ did not $(p=0.11)$. Conclusions: WRF, defined as
\end{abstract}

an absolute change in serum creatinine, is heavily biased by baseline renal function. An alternative definition of WRF should be considered for future studies of cardio-renal interactions.

Copyright ๑ 2010 S. Karger AG, Basel

\section{Introduction}

The strong relationship between chronic renal insufficiency and adverse outcomes in heart failure has been well described [1-7]. More recently, attention has shifted to the adverse prognosis associated with worsening renal function (WRF), commonly defined as an absolute increase in serum creatinine $\geq 0.3 \mathrm{mg} / \mathrm{dl}$, during the treatment of acute decompensated heart failure. Complicating approximately one third of heart failure admissions, WRF has been associated with increased length of stay, readmission rate, and increased short- and long-term mortality [3, 8-13]. Despite the numerous publications in this area, there has been little progress toward elucidating the mechanism for WRF. The majority of these investigations have demonstrated patient characteristics, hemodynamic parameters, and treatment modalities previously assumed causal to have no association or even an inverse association with WRF [3, 8-11, 14-17]. Across these

\section{KARGER}

Fax +4161306 1234 E-Mail karger@karger.ch www.karger.com
() 2010 S. Karger AG, Basel

0008-6312/10/1163-0206\$26.00/0

Accessible online at:

www.karger.com/crd
Jeffrey M. Testani, MD

Hospital of the University of Pennsylvania

3400 Spruce Street, 8 Gates Pavilion

Philadelphia, PA 19104 (USA)

Tel. +1 215662 7355, Fax +1 215349 5734, E-Mail jeffrey.testani@ uphs.upenn.edu 
studies, the most frequently observed risk factor for WRF has been baseline renal insufficiency.

As research in the area of cardiac-renal interactions has progressed from description of prognostic effects to more mechanistically based investigations, the most commonly used definition for worsening renal function has remained an absolute increase in serum creatinine, generally $\geq 0.3 \mathrm{mg} / \mathrm{dl}$ [12]. Serum creatinine has an exponential relationship with estimated glomerular filtration rate (GFR) $[12,18]$. As a result, even a modest absolute increase in serum creatinine can represent either a small or large relative change in renal function, depending on the baseline serum creatinine level. Given this non-linear relationship, we hypothesized that WRF defined by an absolute increase in creatinine is biased by baseline renal function. Additionally, we hypothesized that the previously described association between WRF and baseline renal function may be an artifact of this exponential relationship.

\section{Methods}

We reviewed all consecutive admissions to the cardiology and internal medicine services at the Hospital of the University of Pennsylvania with a primary discharge diagnosis of congestive heart failure from January 1, 2004 to December 1, 2008. Additional inclusion criteria included a B-type natriuretic peptide level within $24 \mathrm{~h}$ of admission and a length of stay of 3 to 10 days. Exclusion criterion was a lack of admission or discharge serum creatinine level. Estimated GFR was calculated by the Modified Diet and Renal Disease equation [19]. WRF by the absolute change in creatinine criteria $\left(\mathrm{WRF}_{\mathrm{CREAT}}\right)$ was defined as an increase in serum creatinine $\geq 0.3 \mathrm{mg} / \mathrm{dl}$ above the admission value at any time during the hospitalization. Decreases in GFR from 10 to $40 \%$, also at any time during the hospitalization, were tested in $5 \%$ intervals for frequency of occurrence and the value with the most similar incidence to $\mathrm{WRF}_{\mathrm{CREAT}}$ was used for comparative analysis. An admission GFR $\leq 60 \mathrm{ml} / \mathrm{min}$ was defined as moderate or severe renal insufficiency. Mortality data was obtained via the Social Security Death Index. Institutional review board approval was obtained for the study.

\section{Statistical Methods}

Values are reported as mean \pm standard deviation or percentile value. Independent Student's t test or the Mann-Whitney U test was used to compare means of independent continuous variables. Pearson's $\chi^{2}$ was used to evaluate categorical variables unless otherwise stated. Correlation is reported as Phi for comparison of two dichotomous variables. Cox regression analysis was used to evaluate mortality rates when there were censored events. The independence of WRF definitions, from baseline renal insufficiency, was determined using logistic regression analysis comparing models with and without the inclusion of the alternative definitions for the evaluation of mortality estimates at discrete time points (i.e. 30 days). Additionally, logistic regression analysis

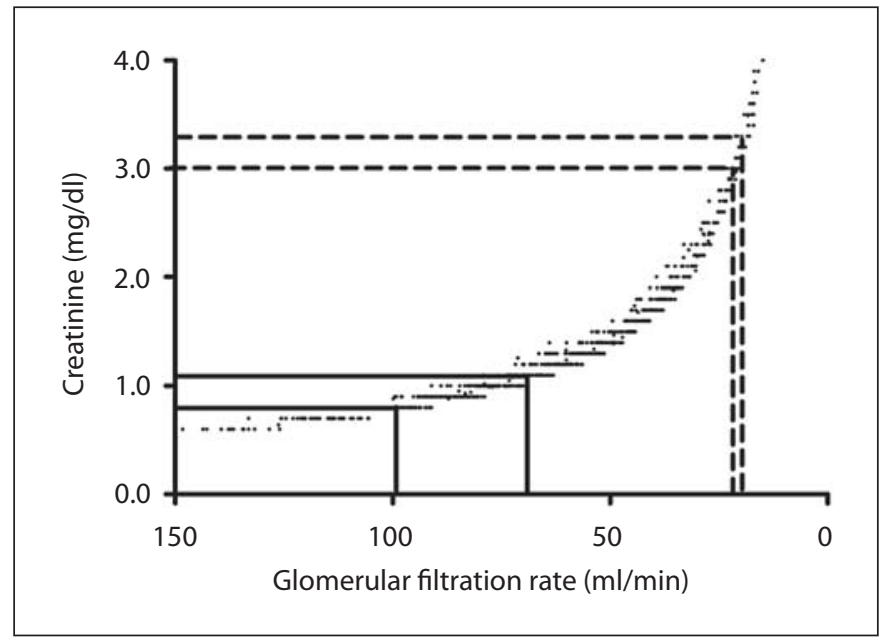

Fig. 1. Relationship between serum creatinine and estimated GFR. The solid lines represent an increase in serum creatinine of $0.3 \mathrm{mg} / \mathrm{dl}$ from the $10 \%$ creatinine value $(0.8 \mathrm{mg} / \mathrm{dl})$ to $1.1 \mathrm{mg} / \mathrm{dl}$ and the corresponding change in estimated GFR. The dashed lines represent a $0.3-\mathrm{mg} / \mathrm{dl}$ increase in serum creatinine from the $90 \%$ percentile value $(3.0 \mathrm{mg} / \mathrm{dl})$ to $3.3 \mathrm{mg} / \mathrm{dl}$ and the corresponding decrease in estimated GFR.

using backward elimination was used to adjust for baseline differences between patients with and without WRF, variables with a univariate $\mathrm{p}$ value $\leq 0.1$ were included in the model. Statistical analysis was performed with SPSS version 17.0 (SPSS Inc., Chicago, Ill., USA) and significance defined as two-tailed $\mathrm{p}<0.05$.

\section{Results}

A total of 993 admissions met eligibility criteria. Baseline characteristics are presented in table 1. A non-linear relationship between serum creatinine and estimated GFR was evident (fig. 1). The 10th percentile for serum creatinine was $0.8 \mathrm{mg} / \mathrm{dl}$ and the 90th percentile was 3.0 $\mathrm{mg} / \mathrm{dl}$ (fig. 1). WRF $\mathrm{CREAT}_{\mathrm{T}}$ occurred in $31.5 \%$ of the population. Table 2 illustrates the incidence of WRF at different percentage decreases in GFR. A decrease in GFR of $20 \%$ had the most similar frequency to $\mathrm{WRF}_{\mathrm{CREAT}}$ and thus was used in subsequent analysis as the relative change in GFR based definition ( $\left.\mathrm{WRF}_{\mathrm{GFR}}\right)$. Of those with $\mathrm{WRF}_{\text {CREAT }}, 80.1 \%$ also had $\mathrm{WRF}_{\mathrm{GFR}}(\mathrm{r}=0.69, \mathrm{p}<0.001)$.

\section{WRF and Baseline Renal Function}

Similar to previous investigations $\mathrm{WRF}_{\mathrm{CREAT}}$ was associated with worse baseline renal function (table 1). The incidence of $\mathrm{WRF}_{\text {CREAT }}$ was significantly greater in those with moderate to severe baseline renal insufficiency 
Table 1. Patient characteristics

\begin{tabular}{|c|c|c|c|c|c|c|c|}
\hline \multirow[t]{2}{*}{ Characteristics } & \multirow{2}{*}{$\begin{array}{l}\text { Overall } \\
\text { cohort }\end{array}$} & \multicolumn{3}{|c|}{$\geq 0.3 \mathrm{mg} / \mathrm{dl}$ increase in creatinine } & \multicolumn{3}{|c|}{$\geq 20 \%$ increase in GFR } \\
\hline & & $\begin{array}{l}\text { WRF } \\
(\mathrm{n}=312)\end{array}$ & $\begin{array}{l}\text { no WRF } \\
(\mathrm{n}=681)\end{array}$ & $\mathrm{p}$ value & $\begin{array}{l}\text { WRF } \\
(\mathrm{n}=324)\end{array}$ & $\begin{array}{l}\text { no WRF } \\
(\mathrm{n}=669)\end{array}$ & $\mathrm{p}$ value \\
\hline \multicolumn{8}{|l|}{ Demographics } \\
\hline Age, years & $61 \pm 16$ & $62 \pm 15$ & $61 \pm 16$ & 0.911 & $61 \pm 16$ & $62 \pm 16$ & 0.554 \\
\hline Males & $52.4 \%$ & $53.0 \%$ & $52.1 \%$ & 0.775 & $48.8 \%$ & $54.1 \%$ & 0.114 \\
\hline African American race & $66.4 \%$ & $65.5 \%$ & $66.9 \%$ & 0.660 & $65.1 \%$ & $67.1 \%$ & 0.533 \\
\hline \multicolumn{8}{|l|}{ Medical history } \\
\hline Coronary artery disease & $42.2 \%$ & $43.7 \%$ & $41.6 \%$ & 0.544 & $40.2 \%$ & $43.3 \%$ & 0.356 \\
\hline Hypertension & $80.4 \%$ & $84.1 \%$ & $78.6 \%$ & $0.046^{*}$ & $81.9 \%$ & $79.6 \%$ & 0.402 \\
\hline Diabetes & $40.7 \%$ & $47.7 \%$ & $37.4 \%$ & $0.002^{*}$ & $39.4 \%$ & $41.3 \%$ & 0.565 \\
\hline \multicolumn{8}{|l|}{ Left ventricular function } \\
\hline Ejection fraction, \% & $33 \pm 21$ & $33 \pm 20$ & $33 \pm 21$ & 0.685 & $32 \pm 21$ & $33 \pm 21$ & 0.552 \\
\hline Ejection fraction $\geq 50 \%$ & $21.6 \%$ & $18.4 \%$ & $22.8 \%$ & 0.193 & $20.2 \%$ & $22.1 \%$ & 0.563 \\
\hline \multicolumn{8}{|l|}{ Admission physical exam } \\
\hline Systolic blood pressure, $\mathrm{mm} \mathrm{Hg}$ & $141 \pm 33$ & $145 \pm 36$ & $139 \pm 32$ & $0.009^{*}$ & $143 \pm 33$ & $140 \pm 33$ & 0.227 \\
\hline Heart rate, beats per minute & $91 \pm 20$ & $91 \pm 19$ & $90 \pm 20$ & 0.584 & $93 \pm 20$ & $89 \pm 19$ & $0.003^{*}$ \\
\hline Jugular venous distention & $65.0 \%$ & $63.0 \%$ & $65.8 \%$ & 0.417 & $65.9 \%$ & $64.5 \%$ & 0.686 \\
\hline Rales $>1 / 2$ lung fields & $8.1 \%$ & $9.1 \%$ & $7.7 \%$ & 0.452 & $8.5 \%$ & $8.0 \%$ & 0.801 \\
\hline$\geq$ Moderate edema & $15.3 \%$ & $15.0 \%$ & $15.5 \%$ & 0.843 & $16.9 \%$ & $14.5 \%$ & 0.332 \\
\hline \multicolumn{8}{|l|}{ Medications (baseline) } \\
\hline ACE inhibitor/ARB & $98.6 \%$ & $98.4 \%$ & $98.7 \%$ & 0.729 & $98.8 \%$ & $98.5 \%$ & 0.742 \\
\hline$\beta$-Blocker & $68.5 \%$ & $70.2 \%$ & $67.6 \%$ & 0.423 & $65.7 \%$ & $69.8 \%$ & 0.201 \\
\hline Loop diuretic, mg & $74 \pm 102$ & $91 \pm 136$ & $66 \pm 80$ & 0.003 & $81 \pm 130$ & $70 \pm 84$ & 0.162 \\
\hline Spironolactone & $14.3 \%$ & $13.0 \%$ & $15.0 \%$ & 0.407 & $14.4 \%$ & $14.4 \%$ & 0.992 \\
\hline Calcium channel blocker & $21.5 \%$ & $24.9 \%$ & $19.9 \%$ & 0.076 & $23.1 \%$ & $20.7 \%$ & 0.405 \\
\hline \multicolumn{8}{|l|}{ Medications (in hospital) } \\
\hline ACE inhibitor/ARB & $78.6 \%$ & $75.5 \%$ & $80.1 \%$ & 0.102 & $81.7 \%$ & $77.2 \%$ & 0.105 \\
\hline$\beta$-Blocker & $84.0 \%$ & $83.9 \%$ & $84.0 \%$ & 0.967 & $82.6 \%$ & $84.6 \%$ & 0.427 \\
\hline Loop diuretic, mg & $140 \pm 122$ & $177 \pm 160$ & $126 \pm 97$ & $0.009^{*}$ & $173 \pm 158$ & $126 \pm 98$ & $0.014^{*}$ \\
\hline Thiazide diuretic & $15.7 \%$ & $48.7 \%$ & $51.3 \%$ & $<0.001^{*}$ & $32.7 \%$ & $67.3 \%$ & $0.003^{*}$ \\
\hline Inotropes & $7.9 \%$ & $10.6 \%$ & $6.6 \%$ & $0.031^{*}$ & $9.9 \%$ & $6.9 \%$ & 0.101 \\
\hline \multicolumn{8}{|l|}{ Medications (discharge) } \\
\hline ACE inhibitor/ARB & $97.6 \%$ & $96.2 \%$ & $98.2 \%$ & $0.048^{*}$ & $96.9 \%$ & $97.9 \%$ & 0.341 \\
\hline$\beta$-Blocker & $83.4 \%$ & $83.3 \%$ & $83.4 \%$ & 0.985 & $81.8 \%$ & $84.1 \%$ & 0.362 \\
\hline Loop diuretic, mg & $95 \pm 107$ & $107 \pm 128$ & $90 \pm 97$ & 0.047 & $96 \pm 112$ & $95 \pm 106$ & 0.82 \\
\hline Spironolactone & $19.1 \%$ & $15.7 \%$ & $20.5 \%$ & 0.076 & $17.9 \%$ & $19.5 \%$ & 0.54 \\
\hline Thiazide diuretic & $8.5 \%$ & $13.0 \%$ & $6.4 \%$ & $0.001^{*}$ & $11.1 \%$ & $7.2 \%$ & $0.038^{*}$ \\
\hline \multicolumn{8}{|l|}{ Laboratory findings (baseline) } \\
\hline Hemoglobin, g/dl & $12.1 \pm 2.1$ & $11.8 \pm 1.9$ & $12.2 \pm 2.1$ & $0.004^{*}$ & $12.1 \pm 1.9$ & $12.1 \pm 2.2$ & 0.893 \\
\hline Serum sodium, $\mathrm{mEq} / \mathrm{l}$ & $139 \pm 4.2$ & $139 \pm 4.5$ & $139 \pm 4.0$ & $0.029^{*}$ & $139 \pm 4.4$ & $139 \pm 4.1$ & 0.706 \\
\hline Serum creatinine, $\mathrm{mg} / \mathrm{dl}$ & $1.8 \pm 1.8$ & $2.2 \pm 2.1$ & $1.6 \pm 1.4$ & $<0.001^{*}$ & $1.5 \pm 1.8$ & $1.9 \pm 1.8$ & $<0.001^{*}$ \\
\hline Glomerular filtration rate, $\mathrm{ml} / \mathrm{min}$ & $60 \pm 32$ & $53 \pm 32$ & $63 \pm 31$ & $<0.001^{*}$ & $68 \pm 32$ & $56 \pm 31$ & $<0.001^{*}$ \\
\hline Moderate to severe renal insufficiency & $54.3 \%$ & $64.7 \%$ & $49.6 \%$ & $<0.001^{*}$ & $43.2 \%$ & $59.7 \%$ & $<0.001^{*}$ \\
\hline B-type natriuretic peptide, $\mathrm{pg} / \mathrm{ml}$ & $1,642 \pm 1,259$ & $1,738 \pm 1,294$ & $1,599 \pm 1,242$ & 0.108 & $1,477 \pm 1,217$ & $1,723 \pm 1,272$ & $0.003^{*}$ \\
\hline \multicolumn{8}{|l|}{ Net fluid/weight loss and length of stay } \\
\hline Length of stay, days & $5.3 \pm 2.1$ & $5.8 \pm 2.1$ & $5.0 \pm 2.0$ & $<0.001^{*}$ & $5.7 \pm 2.1$ & $5.1 \pm 2.0$ & $<0.001^{*}$ \\
\hline Net fluid out, 1 & $4.8 \pm 8.0$ & $5.4 \pm 11.9$ & $4.6 \pm 5.8$ & 0.212 & $4.7 \pm 5.8$ & $4.9 \pm 8.8$ & 0.797 \\
\hline Net weight lost, $\mathrm{kg}$ & $3.8 \pm 10.7$ & $2.9 \pm 15.1$ & $4.1 \pm 7.8$ & 0.21 & $3.5 \pm 16.3$ & $3.9 \pm 6.0$ & 0.669 \\
\hline
\end{tabular}

$\mathrm{ACE}=$ Angiotensin-converting enzyme inhibitor; $\mathrm{ARB}=$ angiotensin receptor blocker; $\mathrm{GFR}=$ estimated glomerular filtration rate; $\mathrm{WRF}=$ worsening renal function. ${ }^{*}$ Significant $\mathrm{p}$ value.

$(\mathrm{OR}=1.9, \mathrm{p}<0.001)$. Similar trends were found by defining baseline renal insufficiency by various admission creatinine thresholds (fig. 2).

$\mathrm{WRF}_{\mathrm{GFR}}$, however, yielded dissimilar results to $W R F_{C R E A T}$ in its relationship to baseline renal function (fig. 2). Admission renal function was significantly higher in those developing $\mathrm{WRF}_{\mathrm{GFR}}$ compared to those patients who did not (table 1). In contrast to $\mathrm{WRF}_{\mathrm{CREAT}}$, patients with baseline renal insufficiency were substantially less likely to develop $\mathrm{WRF}_{\mathrm{GFR}}(\mathrm{OR}=0.51, \mathrm{p}<0.001)$. To 
Table 2. Incidence of WRF defined by percent decrease in GFR

GFR = Estimated glomerular filtration rate; $\mathrm{WRF}=$ worsening renal function.

\begin{tabular}{ll}
\hline GFR threshold & Incidence of WRF \\
\hline $10 \%$ & $58.0 \%$ \\
$15 \%$ & $42.8 \%$ \\
$20 \%$ & $32.6 \%$ \\
$25 \%$ & $22.6 \%$ \\
$30 \%$ & $14.7 \%$ \\
$35 \%$ & $9.4 \%$ \\
$40 \%$ & $5.6 \%$ \\
\hline
\end{tabular}

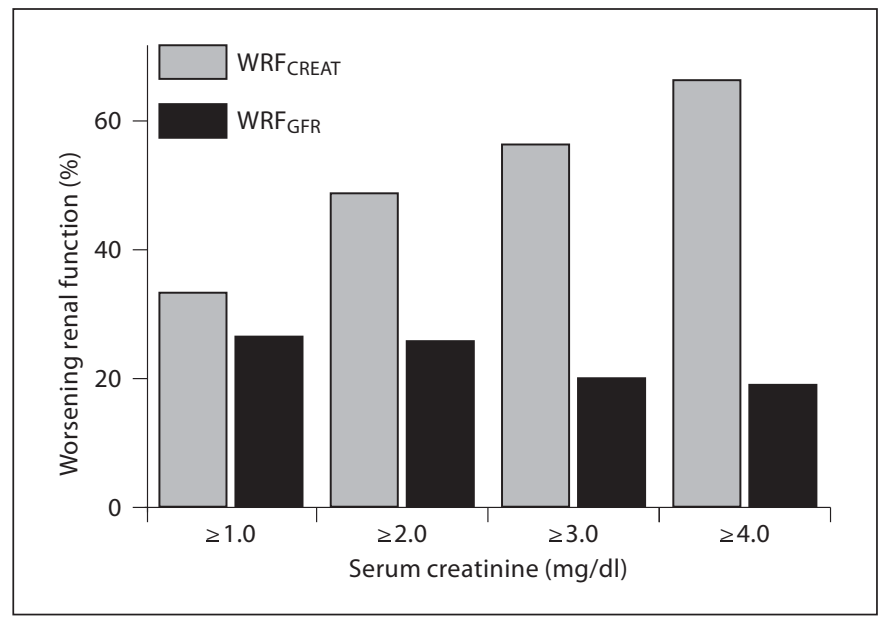

Fig. 2. Incidence of WRF in patients with baseline renal insufficiency defined by different serum creatinine levels. $\mathrm{WRF}_{\mathrm{CREAT}}=$ Worsening renal function defined as increase in serum creatinine by $\geq 0.3 \mathrm{mg} / \mathrm{dl}$; $\mathrm{WRF}_{\mathrm{GFR}}=$ worsening renal function defined as a decrease in estimated GFR of $\geq 20 \%$.

creatinine levels, a subanalysis was performed utilizin only patients with an admission creatinine less than 2.0 $\mathrm{mg} / \mathrm{dl}(\mathrm{n}=776)$. This demonstrated a similar association between $\mathrm{WRF}_{\mathrm{GFR}}$ and moderate to severe baseline renal insufficiency (OR 0.52, p < 0.001); however, the association between $\mathrm{WRF}_{\mathrm{CREAT}}$ and baseline renal insufficiency was no longer significant $(p=0.39)$.

Similar to prior reports, patients developing $\mathrm{WRF}_{\text {CREAT }}$ had a significantly higher incidence of diabetes $(\mathrm{OR}=1.5, \mathrm{p}=0.002)$ and hypertension $(\mathrm{OR}=1.4$, $\mathrm{p}<0.046$; table 1). Interestingly, $\mathrm{WRF}_{\mathrm{GFR}}$ had no association with these variables (diabetes $\mathrm{p}=0.57$, hypertension $\mathrm{p}=0.40$; table 1 ). This discrepancy may be somewhat explained by the strong association between baseline renal insufficiency and both diabetes $(\mathrm{OR}=1.5, \mathrm{p}=0.001)$ and hypertension $(\mathrm{OR}=1.9, \mathrm{p}<0.001)$.

\section{Prediction of Mortality}

Moderate to severe renal insufficiency was a powerful predictor of total mortality $(\mathrm{HR}=2.0, \mathrm{p}<0.0001)$ and was associated with both early and late post-discharge death (table 3). An elevated baseline serum creatinine was also predictive of mortality, but was an inferior metric to baseline GFR (table 3). WRF by either definition predicted early mortality, but did not significantly predict late mortality (table 3). Both $\mathrm{WRF}_{\mathrm{CREAT}}$ and $\mathrm{WRF}_{\mathrm{GFR}}$ had a similar ability to predict 30 day mortality (table 3 ). Focusing on this endpoint, the independence of WRF from baseline renal insufficiency was investigated using logistic regression. Adding $\mathrm{WRF}_{\mathrm{CREAT}}$ to a model with moderate to severe renal insufficiency did not significantly add to the predictive ability of the model (likelihood ratio test $\chi^{2}=2.5, p=0.11$ ) and the adjusted odds ratios for both variables decreased (moderate to severe renal insufficiency $\mathrm{OR}=2.7$ to $2.5, \mathrm{p}=0.018$ to $0.04, \mathrm{WRF}_{\mathrm{CREAT}}$ $\mathrm{OR}=2.1$ to $1.9, \mathrm{p}=0.047$ to 0.11 ). Adding $\mathrm{WRF}_{\mathrm{GFR}}$ to a model containing moderate to severe renal insufficiency led to a significant improvement in the predictive power of the model (likelihood ratio test $\chi^{2}=6.6, p=0.01$ ). The adjusted odds ratios predicting 30 day mortality for both baseline renal insufficiency ( $\mathrm{OR}=2.7$ to $3.2, \mathrm{p}=0.018$ to $0.009)$ and $\mathrm{WRF}_{\mathrm{GFR}}(\mathrm{OR}=2.3$ to $2.7, \mathrm{p}=0.026$ to 0.009$)$ improved significantly upon the addition of $\mathrm{WRF}_{\mathrm{GFR}}$ to the model, likely a result of the inverse correlation between these two variables $(\mathrm{OR}=0.51, \mathrm{p}<0.001)$. Addition of $\mathrm{WRF}_{\text {CREAT }}$ to a model including baseline renal insufficiency and $\mathrm{WRF}_{\mathrm{GFR}}$ did not add incrementally to the model and left WRF $\mathrm{CREAT}_{\mathrm{T}}$ with no independent predictive power (likelihood ratio test $\chi^{2}=0.37, \mathrm{p}=0.54$; $\mathrm{OR}=$ $0.68, \mathrm{p}=0.55)$.

To further explore the influence of baseline characteristics on the association between mortality and WRF, logistic regression with backward elimination was employed. Controlling for baseline differences between those with and without $\mathrm{WRF}_{\mathrm{GFR}}$ (moderate to severe renal insufficiency, B-type natriuretic peptide, blood urea nitrogen, nitrate use, hydralazine use, and heart rate) further strengthened the association with 30-day mortality $(\mathrm{OR}=2.8, \mathrm{p}=0.010)$. However, controlling for baseline differences between patients that did and did not develop $\mathrm{WRF}_{\text {CREAT }}$ (moderate to severe renal insufficiency, se- 
Table 3. Association with mortality over time by different definitions of baseline renal insufficiency and WRF

\begin{tabular}{|c|c|c|c|c|c|c|c|c|}
\hline \multirow[t]{2}{*}{ Time } & \multicolumn{2}{|c|}{$\mathrm{GFR}<60 \mathrm{ml} / \mathrm{min}$} & \multicolumn{2}{|c|}{ Baseline creatinine $>1.5$} & \multicolumn{2}{|c|}{$\mathrm{WRF}_{\text {CREAT }}$} & \multicolumn{2}{|c|}{$\mathrm{WRF}_{\mathrm{GFR}}$} \\
\hline & OR & $\mathrm{p}$ & OR & $\mathrm{p}$ & OR & $\mathrm{p}$ & OR & $\mathrm{p}$ \\
\hline 7 days & 8.5 & $0.014^{*}$ & 4.0 & 0.27 & 6.0 & $0.003^{*}$ & 5.6 & $0.004^{*}$ \\
\hline 14 days & 6.0 & $0.007^{*}$ & 2.5 & 0.68 & 3.7 & $0.007^{*}$ & 4.7 & $0.002^{*}$ \\
\hline 30 days & 2.7 & $0.018^{*}$ & 1.4 & 0.37 & 2.1 & $0.047^{*}$ & 2.3 & $0.026^{*}$ \\
\hline 60 days & 2.9 & $0.002^{*}$ & 1.3 & 0.35 & 1.5 & 0.17 & 1.3 & 0.4 \\
\hline 90 days & 3.2 & $<0.001^{*}$ & 1.7 & 0.3 & 1.5 & 0.1 & 1.3 & 0.4 \\
\hline 6 months & 3.1 & $<0.001^{*}$ & 2.0 & $<0.001^{*}$ & 1.1 & 0.6 & 0.91 & 0.7 \\
\hline 1 year & 2.2 & $<0.001^{*}$ & 1.8 & $<0.001^{*}$ & 1.0 & 0.95 & 0.83 & 0.3 \\
\hline
\end{tabular}

$\mathrm{WRF}=$ Worsening renal function; GFR = estimated glomerular filtration rate; $\mathrm{WRF}_{\mathrm{CREAT}}=$ worsening renal function defined as increase in serum creatinine by $\geq 0.3 \mathrm{mg} / \mathrm{dl} ; \mathrm{WRF}_{\mathrm{GFR}}=$ worsening renal function defined as a decrease in GFR of $\geq 20 \%$. ${ }^{*}$ Significant $\mathrm{p}$ value.

rum sodium, hemoglobin, loop diuretic dose, blood urea nitrogen, nitrate use, hydralazine use, calcium channel blocker use, systolic blood pressure, hypertension, diabetes, and admission to the advanced heart failure service) eliminated the significance of the association with 30 day mortality $(\mathrm{OR}=1.6, \mathrm{p}=0.29)$. Removal of baseline renal insufficiency from this model did not significantly alter the results $(\mathrm{OR}=1.6, \mathrm{p}=0.29)$.

\section{Discussion}

The primary finding of this study is the lack of independence between WRF, defined as $\geq 0.3 \mathrm{mg} / \mathrm{dl}$ absolute increase in serum creatinine, with baseline renal insufficiency and the independence of WRF when defined as a relative change in GFR. By using a definition of WRF that is independent of baseline renal insufficiency, the previously reported positive association between WRF and renal insufficiency actually became a negative association. Similarly, the association between WRF and both diabetes and hypertension, two variables strongly associated with baseline renal function, is no longer present when WRF is defined using a relative change in GFR. Additionally, after adjusting for of baseline renal insufficiency and $\mathrm{WRF}_{\mathrm{GFR}}, \mathrm{WRF}_{\mathrm{CREAT}}$ is left without incremental prognostic ability.

The findings of this study are not unexpected given the well-known exponential relationship between serum creatinine and renal function which was also observed in this population (fig. 1) [18]. By classifying WRF as an absolute increase in serum creatinine, an obligatory depen- dent relationship is created between baseline renal function and WRF. For example, a 65-year-old white female with an increase in serum creatinine from 2.5 to $2.8 \mathrm{mg} /$ $\mathrm{dl}$ would meet the $\mathrm{WRF}_{\mathrm{CREAT}}$ definition, but only have had an estimated decrease in GFR of $2.5 \mathrm{ml} / \mathrm{min}$, or a $12 \%$ reduction in GFR. On the contrary, a 35-year-old black male with a creatinine of 0.8 which increases to 1.1 will suffer a $43.5-\mathrm{ml} / \mathrm{min}(31 \%)$ reduction in GFR. As illustrated above, a definition of WRF employing a percentage change in GFR likely better describes the physiology relevant to WRF.

The failure of WRF to predict late mortality in this cohort is not inconsistent with the published literature on this subject. Previous investigators have described the failure of WRF to predict late mortality $[9,20]$ or mortality at any time point $[14,21]$. Additionally, a substantial diminution in predictive power over time was noted in a recent meta-analysis [11]. Given that a large proportion of the publications on this subject have been retrospective series or sub-analyses, publication bias is likely operative and the ability of WRF to predict late outcomes may be inferior to that suggested by much of the current literature. Additionally, the similar unadjusted prognostic ability of a percentage change in GFR and WRF CREAT is consistent with prior reports $[22,23]$.

The finding that $\mathrm{WRF}_{\mathrm{GFR}}$ has an inverse association with baseline renal insufficiency may initially seem counterintuitive. The explanation, however, likely resides in the fact that the treating physicians were not blinded to the patients' renal function during treatment. It is probable that relatively similar changes in renal function trigger different treatment decisions based on creatinine lev- 
el. For example, it is quite possible that an increase in creatinine from 2.5 to $3.2 \mathrm{mg} / \mathrm{dl}$ may trigger a change in management, such as discontinuation of diuresis, while an increase in creatinine from 0.8 to $1.1 \mathrm{mg} / \mathrm{dl}$ would not, even though they both represent an approximately onethird reduction in GFR. Although discontinuation of diuresis may or may not be the correct course of action in the above examples, it would certainly influence the relationship between $\mathrm{WRF}_{\mathrm{GFR}}$ and baseline renal function. Moreover, in a sub-study of the Evaluation Study of Congestive Heart Failure and Pulmonary Artery Catheterization Effectiveness (ESCAPE) trial, we have recently described a strong association between surrogates for aggressive diuresis and improved survival despite a substantially increased incidence of WRF [24]. If these observations prove correct, premature discontinuation of diuresis due to small absolute changes in serum creatinine may negatively impact survival.

Although serum creatinine-based estimates of GFR, such as the Modification of Diet in Renal Disease (MDRD) equation used in this study, are the most commonly used tools for estimation of renal function today, they are at best imperfect measures of renal function. Creatinine is not an ideal filtration marker in that its serum concentration can be significantly affected by dietary intake, tubular secretion, extrarenal clearance, and body composition [25]. Additionally, during the treatment of acute decompensated heart failure rapid changes in both volume and renal function can outpace the rate at which serum creatinine can re-equilibrate, thus adding additional error to the estimation. Superior measures of renal function likely exist, such as cystatin $\mathrm{C}$, and combined equations featuring both cystatin $\mathrm{C}$ and serum creatinine may provide more accurate results than either method alone [26-28]. Additionally, alternative biomarkers, such as serum neutrophil gelatinase-associated lipocalin, which actually indicates injury rather than filtration, may further illuminate this area of research. Although serum creatinine based estimates of GFR are less than ideal, their use will likely persist for some time, and thus it is important not to add additional confounding to the situation with a flawed definition for WRF.

\section{Limitations}

This study is subject to the limitations inherent to retrospective data collection; however, the large sample size and sequential nature of selection offsets some of these limitations. These data are derived from a single center and thus generalizability is somewhat limited. Given the aim of this study is to influence future cardio-renal re- search endpoint selection, the large use of resources necessary for prospective multicenter collection of this data would be difficult to justify. Inclusion of additional clinical endpoints to mortality may further strengthen our conclusions. The use of the Social Security Death Index has been reported to have a small, but not negligible, miss rate. However, given that our objectives was the comparison of mortality between groups, and not study of absolute death rates, this is unlikely to have biased our results significantly. Additionally, the use of the MDRD equation to estimate renal function is a significant limitation given the lack of validation in this population. The primary results of this study should be interpreted as a challenge to the practice of defining WRF with absolute changes in creatinine, not that a relative change in MDRD derived GFR is the optimal definition.

\section{Conclusion}

An absolute increase in serum creatinine of $\geq 0.3 \mathrm{mg} /$ $\mathrm{dl}$, while a well validated predictor of outcomes, is heavily biased by baseline renal function. In this population, the frequently reported association between WRF and baseline renal function, diabetes, and hypertension was no longer present when WRF was defined by a relative change in GFR. Both $\mathrm{WRF}_{\mathrm{GFR}}$ and $\mathrm{WRF}_{\text {CREAT }}$ had similar univariate associations with 30-day mortality; however, only $\mathrm{WRF}_{\mathrm{GFR}}$ demonstrated this association independently of baseline renal function. Given that much of the contemporary focus of research in this area has shifted from the description of prognosis to more mechanistically oriented investigations of cardio-renal interactions, a variable more linearly related to the changes in renal function, such as a percentage change in GFR, may be better suited to capture the relevant physiology.
References

Cardiology 2010;116:206-212
Dries DL, Exner DV, Domanski MJ, Greencations of renal insufficiency in asymptomatic and symptomatic patients with left ventricular systolic dysfunction. J Am Coll

$\checkmark 2$ Campbell RC, Sui X, Filippatos G, Love TE, Wahle C, Sanders PW, et al: Association of chronic kidney disease with outcomes in chronic heart failure: a propensity-matched study. Nephrol Dial Transplant 2009;24: 186-193. berg B, Stevenson LW: The prognostic impliCardiol 2000;35:681-689. 
3 Akhter MW, Aronson D, Bitar F, Khan S, Singh H, Singh RP, et al: Effect of elevated admission serum creatinine and its worsening on outcome in hospitalized patients with decompensated heart failure. Am J Cardiol 2004;94:957-960.

$\checkmark 4$ Formiga F, Chivite D, Manito N, Casas S, Riera A, Pujol R: Predictors of in-hospital mortality present at admission among patients hospitalised because of decompensated heart failure. Cardiology 2007;108:73-78.

5 Heywood JT, Fonarow GC, Costanzo MR, Mathur VS, Wigneswaran JR, Wynne J, et al: High prevalence of renal dysfunction and its impact on outcome in 118,465 patients hospitalized with acute decompensated heart failure: a report from the ADHERE database. J Card Fail 2007;13:422-430.

6 Ochiai ME, Barretto AC, Oliveira MT Jr, Munhoz RT, Morgado PC, Ramires JA: Uric acid renal excretion and renal insufficiency in decompensated severe heart failure. Eur J Heart Fail 2005;7:468-474.

7 Naruse H, Ishii J, Kawai T, Hattori K, Ishikawa M, Okumura M, et al: Cystatin $\mathrm{C}$ in acute heart failure without advanced renal impairment. Am J Med 2009;122:566-573.

$\checkmark 8$ Forman DE, Butler J, Wang Y, Abraham WT, O'Connor CM, Gottlieb SS, et al: Incidence, predictors at admission, and impact of worsening renal function among patients hospitalized with heart failure. J Am Coll Cardiol 2004;43:61-67.

9 Cowie MR, Komajda M, Murray-Thomas T, Underwood J, Ticho B; POSH Investigators: Prevalence and impact of worsening renal function in patients hospitalized with decompensated heart failure: results of the prospective outcomes study in heart failure (POSH). Eur Heart J 2006;27:1216-1222.

-10 Butler J, Forman DE, Abraham WT, Gottlieb SS, Loh E, Massie BM, et al: Relationship between heart failure treatment and development of worsening renal function among hospitalized patients. Am Heart J 2004;147: 331-338.
11 Damman K, Navis G, Voors AA, Asselbergs FW, Smilde TD, Cleland JG, et al: Worsening renal function and prognosis in heart failure: systematic review and meta-analysis. J Card Fail 2007;13:599-608.

-12 Metra M, Nodari S, Parrinello G, Bordonali T, Bugatti S, Danesi R, et al: Worsening renal function in patients hospitalised for acute heart failure: clinical implications and prognostic significance. Eur J Heart Fail 2008; 10: 188-195.

13 Damman K, Jaarsma T, Voors AA, Navis G, Hillege HL, van Veldhuisen DJ, et al: Both in- and out-hospital worsening of renal function predict outcome in patients with heart failure: results from the Coordinating Study Evaluating Outcome of Advising and Counseling in Heart Failure $(\mathrm{COACH})$. Eur J Heart Fail 2009;11:847-854.

- 14 Nohria A, Hasselblad V, Stebbins A, Pauly DF, Fonarow GC, Shah M, et al: Cardiorenal interactions: insights from the ESCAPE trial. J Am Coll Cardiol 2008;51:1268-1274.

15 Mullens W, Abrahams Z, Francis GS, Skouri HN, Starling RC, Young JB, et al: Sodium nitroprusside for advanced low-output heart failure. J Am Coll Cardiol 2008;52:200-207.

16 Mullens W, Abrahams Z, Francis GS, Sokos G, Taylor DO, Starling RC, et al: Importance of venous congestion for worsening of renal function in advanced decompensated heart failure. J Am Coll Cardiol 2009;53:589-596.

-17 Klein L, Massie BM, Leimberger JD, et al: Admission or changes in renal function during hospitalization for worsening heart failure predict postdischarge survival: results from the outcomes of a prospective trial of intravenous milrinone for exacerbations of chronic heart failure (OPTIME-CHF). Circ Heart Fail 2008;1:25-33.

18 Delanaye P, Cohen EP: Formula-based estimates of the GFR: equations variable and uncertain. Nephron Clin Pract 2008;110:c48c53; discussion c54.

19 Levey AS, Coresh J, Greene T, Stevens LA, Zhang YL, Hendriksen S, et al: Using standardized serum creatinine values in the modification of diet in renal disease study equation for estimating glomerular filtration rate. Ann Intern Med 2006;145:247254.
20 Owan TE, Hodge DO, Herges RM, Jacobsen SJ, Roger VL, Redfield MM: Secular trends in renal dysfunction and outcomes in hospitalized heart failure patients. J Card Fail 2006;12:257-262.

-21 Logeart D, Tabet JY, Hittinger L, Thabut G, Jourdain P, Maison P, et al: Transient worsening of renal function during hospitalization for acute heart failure alters outcome. Int J Cardiol 2008;127:228-232.

-22 Gottlieb SS, Abraham W, Butler J, Forman DE, Loh E, Massie BM, et al: The prognostic importance of different definitions of worsening renal function in congestive heart failure. J Card Fail 2002;8:136-141.

-23 Smith GL, Vaccarino V, Kosiborod M, Lichtman JH, Cheng S, Watnick SG, et al: Worsening renal function: what is a clinically meaningful change in creatinine during hospitalization with heart failure? J Card Fail 2003;9:13-25.

24 Testani JM, Chen J, McCauley BD, Kimmel SE, Shannon RP: Potential effects of aggressive decongestion during the treatment of decompensated heart failure on renal function and survival. Circulation 2010;122:265272 .

25 Brenner BM, Rector FC: Brenner and Rector's The Kidney, ed 8. Philadelphia, Saunders Elsevier, 2008.

26 Tidman M, Sjostrom P, Jones I: A comparison of GFR estimating formulae based upon s-cystatin C and s-creatinine and a combination of the two. Nephrol Dial Transplant 2008;23:154-160.

27 Ma YC, Zuo L, Chen JH, Luo Q, Yu XQ, Li Y, et al: Improved GFR estimation by combined creatinine and cystatin C measurements. Kidney Int 2007;72:1535-1542.

$>28$ Stevens LA, Coresh J, Schmid CH, Feldman HI, Froissart M, Kusek J, et al: Estimating GFR using serum cystatin $\mathrm{C}$ alone and in combination with serum creatinine: a pooled analysis of 3,418 individuals with CKD. Am J Kidney Dis 2008;51:395-406. 